Atıf / Citation: Bikorimana, G., Rutikanga, C., Butare, G. W., Safari, K. \& Bahizi, M. 2021. Empirical analysis of foreign direct investment on economic growth: evidence from the East African community. International Review of Economics and Management, 9(2), 114-135. Doi: http://dx.doi.org/10.18825/iremjournal.977022 (Araştırma Makalesi / Research Article)

\title{
EMPIRICAL ANALYSIS OF FOREIGN DIRECT INVESTMENT ON ECONOMIC GROWTH: EVIDENCE FROM THE EAST AFRICAN COMMUNITY
}

\author{
Gerard BIKORIMANA ${ }^{1}$ Charles RUTIKANGA $^{2}$ \\ George Wycliffe BUTARE ${ }^{3}$ Kambanda SAFARI $^{4}$
}

Marcel BAHIZI

Başvuru / Submitted: 07 / 08 / 2021 - Kabul / Accepted: 04 / 10 / 2021

\begin{abstract}
This paper examines the impact of foreign direct investment on economic growth in the East Africa Community throughout the period 1970-2017. The study used the Pedroni test of cointegration to test the long-run relationship and the VECM tool to inspect the long- run and short-run granger causality between Foreign Direct Investment (FDI) and economic growth. The paper confirmed the integration of order one among the variables under study. The results from the Pedroni cointegration and Vector Error Correction Model (VECM) found that FDI was statistically significant and positively associated to economic growth in the member states of the East African Community (EAC). The gross capital formation also correlated positively with economic progress in the region, while inflation and population growth negatively correlated with economic growth, and thus, the government final consumption expenditure and trade were negatively and positively statistically insignificant respectively. The VECM granger causality exploration discovered a bi-directional granger causality between GDP per capita and population growth. Regarding the policy perspective, the study recommended the member states of the East African Community to strengthen foreign direct investment policy through providing incentives to investors, and providing basic infrastructure, as well as the establishment of a better macroeconomic environment.
\end{abstract}

Keywords: FDI, Economic growth, East African Community, Padroni Cointegration, VECM Jel Classification: F21, F36, F43, O40

\footnotetext{
${ }^{1}$ University of Rwanda, College of Arts and Social Sciences, bikogerard@ gmail.com, iD https://orcid.org/0000-0002-3497-5186

${ }^{2}$ University of Rwanda, College of Arts and Social Sciences, rutix2020@yahoo.co.in, iD https://orcid.org/0000-0002-9190-5360

${ }^{3}$ University of Rwanda, College of Arts and Social Sciences, georgia21@usa.com, ID https://orcid.org/0000-0002-2352-0303

${ }^{4}$ University of Rwanda, College of Arts and Social Sciences, kumsafari@yahoo.fr, iD https://orcid.org/0000-0002-5795-6009

${ }^{5}$ Rwanda Food and Drugs Authority, Kigali, Rwanda, bahimarce@yahoo.fr, 1 https://orcid.org/0000-0002-8855-3456
} 
Bikorimana, G., Rutikanga, C., Butare, G. W., Safari, K. \& Bahizi, M. 2021. Empirical analysis of foreign direct investment on economic growth: evidence from the East African community. International Review of Economics and Management, 9(2), 114-135.

\section{INTRODUCTION}

Foreign direct investment (FDI) is viewed as a crucial cornerstone for economic progress in the contemporary economic scene worldwide. Economic progress and its contributing factors have been emphasized in the previous studies, particularly in many emerging states. FDI is taken as the engine for economic growth in terms of offering new investment and in terms of upgrading technologies as well as promoting professional knowledge in the country. FDI is mostly oriented towards the manufacturing sector and other important development infrastructures that offer a more comparative advantage.

Foreign direct investment has performed a fundamental role in speeding up growth and economic development among under-developing nations, including the East African Community member states that have appealed. Also, Foreign direct investment (FDI) has turned into the biggest distinct source of foreign finance for unindustrialized economies; FDI has served as a means of technology transfer from developed to under-developing countries, it attracts domestic capital speculation and enables countries to upgrade human and institutional development of beneficial countries. Pegkas, (2015) hypothesizes that FDI contributes to raising the degree of technical improvement in the beneficiary states through knowledge dissemination referred to as externalities or efficacy overflows from technology transfer and professional management skills applied by overseas firms.

Amongst the variables of foreign direct investment and others determining factors of economic progress, similar local investments, exports, human development, research, and development expenses. Specifically, FDI impacts positively welcome nations because of the upsurge of endowment for local investment. Kevin, (2001) showed that FDI has two main substantial payoffs on local investment by contending with production and monetary markets. Hence, FDI contributes to attaining progress in two main ways such as (i) upsurging overall investment by stimulating a greater magnitude of local investment, (ii) across the interaction of innovative technology by the host's human resources, FDI has more benefits of productivity compared to local investment. Also, FDI contributes to the new member states by raising its volume of export by generating new job opportunities (Stmatiou \& Dritsakis, 2013).

Many countries worldwide have made serious contributions by establishing an attractive investment environment and making investment strategies to entice FDI. These include trade liberalization strategies, increasing competition, privatization of government- 
Bikorimana, G., Rutikanga, C., Butare, G. W., Safari, K. \& Bahizi, M. 2021. Empirical analysis of foreign direct investment on economic growth: evidence from the East African community. International Review of Economics and Management, 9(2), 114-135.

owned enterprises, minimization of state supervision in the private sector, decreasing tax regimes and introducing a new environment of legal reforms (Bellak \& Leibrecht, 2016). This is supported by the upsurge in the size of FDI inflows worldwide, which were approximated to around \$1.87 trillion in 2016 (UNCTAD, 2018).

The East African Community which comprises six member countries, has attracted substantial foreign direct investment inflows. Principally, the fusion and attainments of companies as well as the venture in the services industry in the EAC have impacted the progress in terms of FDI (Adeyeye \& Olawumi, 2016). The opening of the doors to the financial sectors of privatization, development of manufacturing as well as the overall economic liberalization of East Africa Community member countries such as Kenya, Tanzania, Uganda, and Rwanda have all impacted positively on the upsurge of foreign direct investment inflows (Penev \& Marusic, 2014).

EAC member states comparatively observed more growth rates during the period 2005-2013; this was equivalent to 6.1 percent or 5.4 percent for Africa in general. According to the IMF (2016) East African Community (EAC) member countries were expected to keep their progress for the period of three years 2014-2016, as the GDP progress in the EAC was estimated to be at 6.6 percent. The motivations provided by member states of EAC, for instance, the Customs Union on the Common Market, import duty exoneration and favorable policies for investment all contributed to the upsurge of FDI inflows. In the 1990s, FDI inflow was nearly insignificant in EAC members. Around 2000, the growth of FDI tripled its yearly inflows that totaled up to $\$ 623$ million. The foreign direct investment (FDI) in EAC increased rapidly compared to Africa with an upsurge share of 3.1 percent in 2001 to 3.8 percent in 2013 (UNCTAD, 2015). Economically, EAC member states policymakers attracted FDI and retained it as a priority to stimulate economic progress (EAC, 2011).

EAC member states experienced substantial economic improvement (UNCTAD, 2015). This led to significant economic growth with FDI inflows that contributed partially to that achievement. In fact, limited research in EAC has been conducted on the contribution of FDI on economic growth Only a few scanty studies focus on Africa in general, such as the study by Adams (2009) who investigated the impact of FDI on the promotion of economic progress in Africa. The findings showed that FDI has an affirmative contribution to the recipient nation. In their comparative research on FDI and economic progress in Africa that used OLS estimation, Olawumi et al., (2017) found that there was a small influence of FDI on economic progress in African states. Elsewhere, in his research on the relationship between 
Bikorimana, G., Rutikanga, C., Butare, G. W., Safari, K. \& Bahizi, M. 2021. Empirical analysis of foreign direct investment on economic growth: evidence from the East African community. International Review of Economics and Management, 9(2), 114-135.

FDI and growth in South Africa, Masipa's (2018) study highlighted affirmative positive association between FDI and economic progress in South Africa. Other studies, focused on FDI and economic growth relationship mostly for some African states outside the EAC (Zekarias, 2016); Sakyi \& Egyir, (2017); Adeyeye \& Olawumi, 2016).

The influence of other East African countries cannot be taken too lightly particularly in the reports of FDI inflows and thus, concentrating on East African countries in general provided proof that makes it difficult to explore the link between FDI and economic growth in EAC. Frequently, empirical evidence of such studies provides a foundation of global investment strategies in the East Africa Community. The shortage of research in the East Africa Community has led to a poor association between foreign direct investment inflows and growth in the EAC. This drawback suggests that research in the East Africa Community is beneficial because it provides an association between foreign direct investment and economic growth. This relationship encourages investment by foreign investors.

The paper seeks to contribute to the existing scanty literature, as many existing studies have been conducted on the association between FDI and growth without any common understanding between economists and scholars on the nature of the association found. The lack of literature in this field shows that there is an urgent need for more investigation on the subject to investigate the association between FDI and economic growth. Under this background, the present study aimed at investigating the impact of FDI on economic growth in EAC over the period of 1990- 2017.

This paper is structured as follows: Section 2 deals with the literature review while Section 3 describes a brief situation of investment in the EAC. In Section 4, the methodology used in collecting and analyzing data is described while Section 5 deals with the findings and discussions. The last section provides a conclusion of the study.

\section{REVIEW OF LITERATURE}

Many studies conducted on the association between foreign direct investment (FDI) and economic growth have been accused of being inconclusive. Some of these studies include the one done by Pegkas, (2015) who analyzed the effect of FDI on growth in the Eurozone states. His findings highlighted the positive and statistical association between FDI and economic progress. in their analysis of FDI and growth, alasubramanyam et al., (1996) revealed that FDI contributed positively to the growth of host countries through various ways 
Bikorimana, G., Rutikanga, C., Butare, G. W., Safari, K. \& Bahizi, M. 2021. Empirical analysis of foreign direct investment on economic growth: evidence from the East African community. International Review of Economics and Management, 9(2), 114-135.

such as the promotion of human development, job creation, and through technological spillover.

While investigating the impact of foreign direct investment (FDI) on economic progress, Borensztein et al., (1998) found that foreign direct investment was one of the ways of promoting technology transfer and providing a comparative advantage in terms of increased production. Thus, the higher production of FDI happened only if the recipient country had the smallest threshold of the available of human resources. Therefore, FDI provides positive support to economic progress only if a suitable absorption of progressive technologies is obtainable in the recipient economy.

The study by Iamsiraroj (2016) investigated the link between FDI and economic growth by applying simultaneous equation system of 124 cross-country information over the period of 1971-2010. The results showed that FDI had an a positive correlation with economic progress of the recipient economy through spillover influences. Magnus et al., (1992) conducted a study on the progress of developing countries by combining 78 under-developing and 23 industrialized countries. The findings showed that foreign direct investment had a substantial contribution to economic progress only for higher income nations during the investigation time frame of 1960-1985. In establishing the link between FDI and economic growth in China by using quarterly data that covered the period of 1981 -1997, Liu et al., (2002) established a bi-directional association between FDI and economic progress in China.

The research conducted by Alfaro et al., (2004) on FDI, financial market, and economic progress using the data obtained from OCED and non-OCED states that covered the period between 1975 and1995. The findings showed that FDI made a positive contribution to economic progress although a certain level of financial growth was needed to accomplish the perspective of FDI. The result from the research done by Alguacil et al., (2011) on inward FDI and economic progress for 26 developing states covering the period of 1976-2005 showed positive FDI impact on economic progress. Such progress existed only for lessincome countries. Using the cointegration method in analyzing the link between FDI and economic progress in Tunisia from 1975 to2009, the findings showed the existence of a longrun association between FDI and economic progress (Soltani \& Ochi, 2012).

Using the estimation of the generalized method of moments (GMM) to explore the linkages between FDI and economic progress in the developing states of the Eastern Caribbean during the period of 1988-2013, affirmative positive impact of FDI on economic 
Bikorimana, G., Rutikanga, C., Butare, G. W., Safari, K. \& Bahizi, M. 2021. Empirical analysis of foreign direct investment on economic growth: evidence from the East African community. International Review of Economics and Management, 9(2), 114-135.

progress was established but its influence was found to be low if perceived in isolation of other factors (Mamingi \& Martin, 2018).

On the other hand, others studies recorded a negative influence of FDI on economic growth. Ang (2009) analyzed the influence of FDI in Thailand's economy from 1970 to 2004 using VECM and IV estimation techniques. He found that FDI influenced economic progress negatively in long- run for Thailand. Elsewhere, the study by Xinfeng \& Majagaiya, (2011) found no association between FDI and economic progress in Nepal during the period 19832007. Another study conducted by Naguib (2012) using ECM estimation on the impact of privatization and FDI on economic progress in Argentina in 1971-2000, found that FDI did not influence economic progress in Argentina both in short-run and long-run. Mounir \&Atef (2018) also found that in Saudi Arabia, FDI negatively affected local investments in the shortrun during the period 1970-2015.

Mah (2010) conducted a study on FDI inflows and economic progress in China during the period 1983-2001. He used the ADF test and found that FDI inflows did not cause economic progress in China. Using the ARDL cointegration test in investigating the contribution of FDI to economic progress in Zimbabwe, Tsaurai \& Odhiambo, (2012) found that there was no link between FDI and economic progress during the study time frame of 1980-2010. Philip \& Adeyemi, (2013) also conducted an investigation on the relationship between FDI and economic progress in the Economic Community of West African States (ECOWAS) during the time lag of 1970-2011 by applying the GMM method. Their findings showed a negative impact of FDI on economic progress in ECOWAS.

Other studies recorded an insignificant correlation between FDI on economic progress. In Tunisia, a study conducted by Belloumi (2014) that used the ADRL approach to establish the link between FDI and trade, and economic progress in Tunisia (1970-2008), found no association between FDI and economic progress. Nicet-Chenaf \& Rougier, (2009) used data from the Middle East and Northern Africa countries (MENA) over the time span of 19752004. They analyzed the FDI and growth relationship and found that FDI did not have any influence on economic progress in the above nations. In investigating whether FDI accelerated economic progress in 72 nations during the time span of 1960-1995, using the GMM estimation, Carkovic \& Levine, (2002) found that FDI did not impact on the economic progress in the long- run. Lastly, in the study by Gunby et, al., (2017) that used the metaanalysis method on whether FDI caused economic progress in China, it was found that the influence of FDI on China's economic progress of was statistically insignificant. 
Bikorimana, G., Rutikanga, C., Butare, G. W., Safari, K. \& Bahizi, M. 2021. Empirical analysis of foreign direct investment on economic growth: evidence from the East African community. International Review of Economics and Management, 9(2), 114-135.

\section{OVERVIEW OF FOREIGN DIRECT INVESTMENT IN EAST AFRICAN COMMUNITY}

The developing nations have been putting emphasis on FDI as the foundation of economic expansion and transformation, income progress, and job creation. The volume and steadiness of the current FDI are mostly acknowledged as a substantial basis of economic growth (Ozturk, 2007; Onyebuchi and Manasseh, 2014; Mehic et al., 2013). FDI is considered as a supplement to the national accumulation, which implies the expansion in terms of production competencies and hence contributes to job creation (Syed \& Muhammad, 2009). Foreign direct investment is supposed to inspire internal savings and persuade hightech advancement by innovation and integration of high-technologies in the production sector (Mehic et al., 2013). In the East Africa Community, FDI inflows have continued to be very low since the 1990s. Nonetheless, relative progress of FDI started to be felt in the initial 2000s, while the yearly average of FDI inflows tripled to the tune of 623 million US dollars. In the previous 14 years, a continuous growth of FDI inflow was registered in the EAC region. In every member state of the EAC, an impressive result of FDI growth was recorded between 2000 and 2014.

For instance, Burundi showed a small but significant improvement in terms of FDI inflow over a period of 14 years. From 2009 to 2014, Tanzania stimulated more FDI inflows with a yearly growth rate of nearly 10 percent. In the same period Uganda's FDI inflow more than doubled from $\$ 842$ million to $\$ 1.1$ billion, respectively, from 2009 to 2014 . As for Rwanda, its FDI doubled from $\$ 119$ to 268 million respectively during the period that ranged from 2009 to 2014. In Kenya, impressive progress was made in terms of FDI inflow from $\$ 115$ to $\$ 989$ during the same period (see Figure 1).

The upsurge in FDI in the EAC countries from 2000 stemmed from the growth of inward foreign direct investments to GDP ratio that rose from 2000 to 2014. Compared to FDI in Africa displays, there is evidence to suggest an upsurge of FDI in the EAC. Specifically, there is still a gap whereby the average of FDI inward stock to GDP in East African Community was 19.4 percent in 2003, likened to the 33.2 percent for the general level in Africa (Penev \& Marusic, 2014). 
Figure 1: FDI Inflows in the East African Community Member States 2000- 2014(US \$ millions)

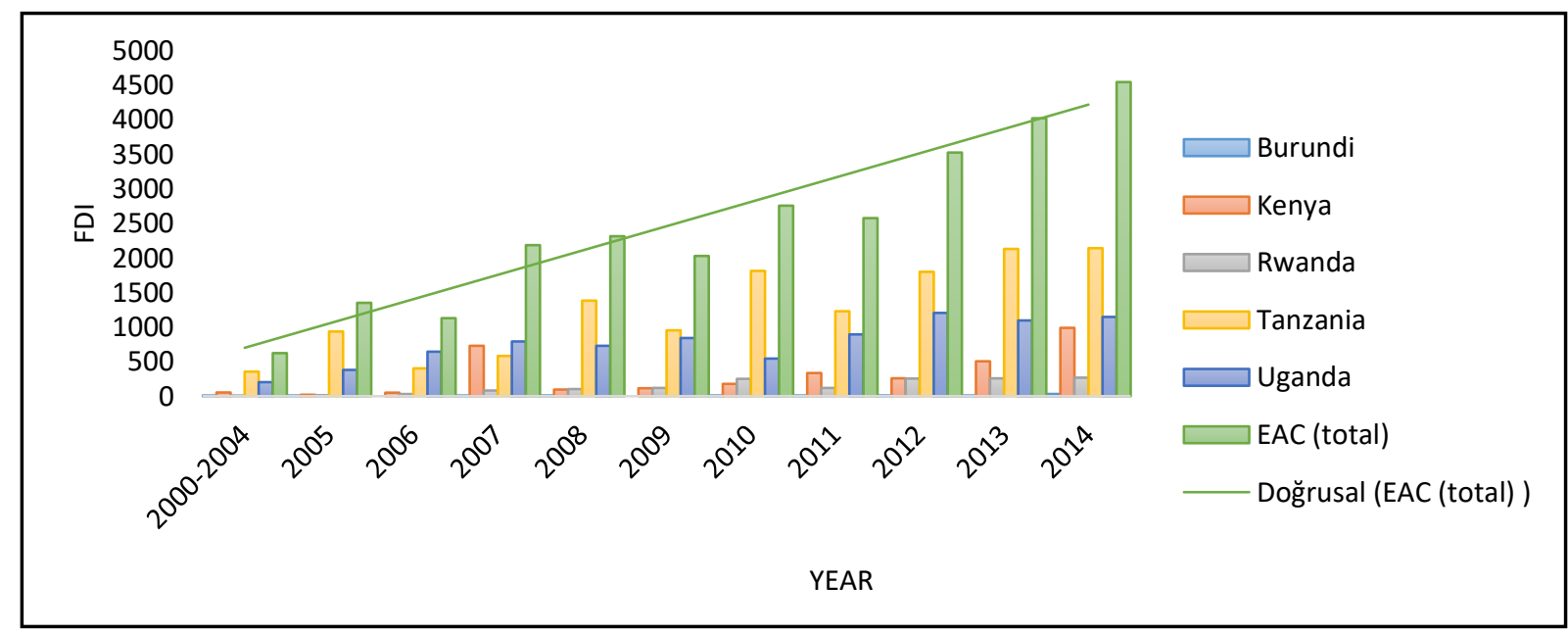

Source: Computed from http://unctad.org/fdistatistics

\section{METHODOLOGY AND DATA}

\section{IV.I. Data}

To analyze the impact of FDI on economic growth in the EAC member states (Rwanda, Burundi, Kenya, Tanzania, and Uganda), the present paper used data that covered the period between 1990 and 2017. South Sudan was excluded from this study due to the shortage of consistent data from that country. In line with the current economic literature, the variables such as GDP per capita growth, foreign direct investment, gross capital formation, population growth rate, inflation, general government final consumption expenditure and trade were used as potential variables in this research. All the data used in this study was obtained from the World Bank dataset of development indicators. Some variables like FDI inflow, gross capital formation, and general government final consumption expenditure were transmuted in natural logarithm. 
Table I. Summary Statistics For The Variables Under Consideration

\begin{tabular}{lcccccc}
\hline Variables & Mean & Median & Maximum & Minimum & $\begin{array}{c}\text { Standard } \\
\text { Deviation }\end{array}$ & Observations \\
\hline $\begin{array}{l}\text { GDP per capital growth (GDP) } \\
\begin{array}{l}\text { logarithm of foreign direct investment } \\
\text { (LFDI) }\end{array}\end{array}$ & 1.630 & 1.931 & 36.981 & -47.806 & 6.192 & 140 \\
$\begin{array}{l}\text { Logarithm of Gross capital formation } \\
\text { (LGCF) }\end{array}$ & 7.465 & 7.997 & 9.320 & 2.000 & 1.543 & 140 \\
& 9.150 & 9.352 & 10.317 & 7.384 & 0.707 & 140 \\
$\begin{array}{l}\text { logarithm of General government final } \\
\text { consumption expenditure (LGGFCE) }\end{array}$ & 9.067 & 9.145 & 9.951 & 8.085 & 0.511 & 140 \\
$\begin{array}{l}\text { Inflation (INF) } \\
\begin{array}{l}\text { Trade (TR) } \\
\text { Population growth rate (POPG) }\end{array}\end{array}$ & 10.200 & 8.087 & 45.979 & -2.406 & 7.910 & 140 \\
\hline
\end{tabular}

Source: Author's computation with data provided

Table 1 presents the summary statistics of the variables that covered the period of 1990 - 2017. As indicated, the GDP per capita growth ranged from -47.806 to 36.981 with a perceived mean of 1.630 and a Standard Deviation (Std. Dev) of 6.192. It can also be noted that foreign direct investment also had an observed mean of 7.465 with a Std. Dev. of 6.192 and a range of 2.000 to 9.320 . For all variables under consideration, the study portrays a positive value for the mean and standard deviation.

\section{IV.II. Theoretical Model Formulation}

The current study was supported by the neoclassical growth model founded by Solow, (1956). In this model, the aggregate production function supposes that, alongside the "conventional inputs" of labor and capital applied in the neoclassical model of the production function, "unconventional inputs" such as FDI are added in the model to measure its contribution to economic progress. Taking into consideration the aggregate production function model to be estimated for any specific economy:

$$
Y_{t}=A_{t} \delta\left(K_{t}, L_{t}, H_{t}\right)
$$

Where $Y_{t}$ designates the total production for any economy at time t, while $K_{t}, L_{t}, H_{t}$ stands for capital stock, labor, and human resources respectively at time $\mathrm{t}$. In addition, $A_{t}$ includes other features which may influence production apart from $K_{t}, L_{t}$, and $H_{t}$. It should be noted that the capital stock comprises the national capital $\left(\mathrm{K}_{\mathrm{n}}\right)$ and the external-possessed capital $\left(\mathrm{K}_{\mathrm{e}}\right)$. This supports the view that the production function for any recipient economy is the Cob- Douglas function. Another assumption is that there is a steady labor force growing 
Bikorimana, G., Rutikanga, C., Butare, G. W., Safari, K. \& Bahizi, M. 2021. Empirical analysis of foreign direct investment on economic growth: evidence from the East African community. International Review of Economics and Management, 9(2), 114-135.

(which signals that population pressure is steady), and thus Eq. (1) is divided by labor $\left(L_{t}\right)$ as indicated in below Eq. (2):

$\frac{Y_{t}}{L_{t}}=A_{t} \delta\left(\frac{K_{t}}{L_{t}}, \frac{L_{t}}{L_{t}}, \frac{H_{t}}{L_{t}}\right)$

Therefore, Eq. (2) is rearranged and squeezed out in terms of Cobb- Douglass production function:

$$
Y_{t}=A_{t} \delta\left(K_{t}, h_{t}\right)=A_{t} K_{t}{ }^{\pi} h^{1-\pi} \quad \text { Record: } K_{t}=k_{n t}+k_{\text {et }}
$$

Where $Y_{t}$ stands for the real per capital gross domestic product at time t, and $\pi$ indicates the share of capital stock. Thus, supposing that there is a diminishing return to the capital, this means that an extra unit of capital is conditioned to the employee while production reduces lesser and lesser. Also, supposing that $\pi<1$ indicates a diminishing return to capital. Therefore, the model supposes that human resources $(\mathrm{H})$ rely on the national capital $\left(\mathrm{K}_{\mathrm{n}}\right)$ and external-possessed capital $\left(\mathrm{K}_{\mathrm{e}}\right)$ (Herzer et al., 2006). By using the CobbDouglass function, it can be denoted as follow:

$h_{t}=\left(k_{n t} k_{e t}^{\lambda}\right)^{\omega}$

The $\lambda$ and $\omega$ stand for marginal elasticity of change-over between national and external capital. Combine both Eq. (3) and (4) to give:

$y_{t}=A_{t} K_{n t}{ }^{\pi+\omega(1-\pi)} K_{e t}^{\lambda \omega(1-\pi)}$

Therefore, basing on Eq. (4) and taking the logarithm on both sides and thereafter using the first difference, this provides Eq. (5):

$g_{y_{t}}=g_{A_{t}}+[\pi+\omega(1-\pi)] g_{n_{t}}+[\lambda \omega(1-\pi)]$

Where $g_{y_{t}}$ denotes the growth rate of general government final consumption expenditure at time $\mathrm{t}(\mathrm{GGFCE}), g_{A_{t}}$ stands for aggregate factors of production growth at time $\mathrm{t}$, while $g_{n_{t}}$ stands for the growth rate of gross domestic capital formation at time $\mathrm{t}$ (GCF), while $g_{e_{t}}$ indicates the growth of external-possessed capital at time $t$ (FDI). The control variables also are encompassed in the model as indicated in Eq. (6) and it is simplified as follows:

$g_{y_{t}}=g_{A_{t}}+\varpi g_{n_{t}}+\psi g_{e_{t}}+\Psi A$ 
Bikorimana, G., Rutikanga, C., Butare, G. W., Safari, K. \& Bahizi, M. 2021. Empirical analysis of foreign direct investment on economic growth: evidence from the East African community. International Review of Economics and Management, 9(2), 114-135.

Where $A_{t}$ includes other factors that influence productivity apart from $K_{t}, L_{t}$, and $H_{t}$, and it encompasses other collection of control and policy variables for instance; general government final consumption expenditure (GGFCE), inflation rate (INF), trade (TR) and population growth rate (POPG). Also, it is denoted as aggregate factors of production which is not considered for by quantity of raw materials employed in production. The selection of policy variables were inspired by the study conducted by Barro, (1991); Laura et al.,(2003); Xinshen et al., (2017).

\section{IV.III. Estimation Method}

To explore the impact of FDI on economic growth in EAC member states, we used the normal practice of time series breakdown. We selected the appropriate estimation techniques of the time series based on the selected research variables. Thus, the present study adopted the use of panel unit root tests, Pedroni panel cointegration, and VECM to provide estimations.

\section{IV.III.I. Panel Unit Root Test}

Before performing the model estimation for time series data, econometricians advise that a verification of unit root between the variables under study should be made and foremost. Otherwise, using a simple information of regression on time series information may produce poor results because it increases the probability of non-stationary data (Dickey, 1979, Perron \& Phillips, 1988). For this reason, the present study applied the panel unit root method to obtain the integration order of variables. Thus, the article adopted the use of panel unit root test proposed (Levin et al., (2002) ; Im et al., 2003), ADF-Fisher chi-square , 1999; and PPFisher chi-square, 2001). These tests, except that of Im et al., (2003)are all supposed to follow a mutual unit root procedure that is pertinent to cross-section crossways. Additionally, the Dickey-Fuller guideline procedure was also used to test the null hypothesis of the unit root. It is specified as follows:

$$
\Delta z_{j t}=\psi+X_{j t} \vartheta+\lambda z_{j t-1}+\Sigma \pi_{j t} \Delta z_{j t-j}+\varpi_{j t}
$$

Where $z_{j t}$ stands for the variable under study while $X_{j t}$ stands for independent variables. As for and $\varpi_{j t}$, it represents the error margin. Lastly, $j=1, \ldots, N$ stands for the cross section- unit (country) and $t=1, \ldots ., T$ stands for the time period involved. 
Bikorimana, G., Rutikanga, C., Butare, G. W., Safari, K. \& Bahizi, M. 2021. Empirical analysis of foreign direct investment on economic growth: evidence from the East African community. International Review of Economics and Management, 9(2), 114-135.

\section{IV.III.II. Pedroni Cointegration Test}

After establishing the order of stationarity, if the variables are integrated at order one (I (1)), then, the cointegration association amongst the variables should be investigated. This study used a panel method to test for variable cointegration as suggested by Pedroni $(1999,2004)$. This technique was deemed reliable because its causation runs in both directions to lead to mixed cointegration vectors within the short-run crossways. In investigating the null hypothesis of non-cointegration, an alternative hypothesis and a Pedroni test was used for 4panel statistics and 3 group panel statistics. Specifically, the cointegration regression for the Pedroni test was based on the following model:

$$
z_{j \mathrm{t}}=\lambda_{j}+\eta_{j} t+\gamma_{j} X_{j \mathrm{t}}+\varpi_{j t}
$$

Where $\lambda_{j}$ and $\eta_{j}$ enabled us to determine country specific fixed effects of series means of , $X_{j \mathrm{t}}$ stands for $\mathrm{k}$ measurement column vector of predictor variables used by every nation $f$, and $\gamma_{j}$ stands for $\mathrm{k}$ measurement row vector used for each country $j$ under study. It was assumed that all variables under the study (response and control variables) were at I (1). To perform the cointegration test, it was compulsory to determine the lag length criteria first. The study used fourth lag length as a major criterion. Thus, in order to analyze the long-run and short- run granger causality amongst the variables under consideration, the VECM method was used while the Wald test was also used to identify the short run causality. Thus, we obtained the vector error correction regression model:

$$
\begin{aligned}
\Delta G D P=\rho_{j}+ & \sum_{j=1}^{k} \lambda_{j k} \Delta G D P_{j t-k}+\sum_{j=1}^{k} \pi_{j k} \Delta F D I_{j t-k}+\sum_{j=1}^{k} \varrho_{j k} \Delta G G F C E_{j t-k}+\sum_{j=1}^{k} \psi_{j k} \Delta G C F_{j t-k} \\
& +\sum_{j=1}^{k} \vartheta_{j k} \Delta I N F_{j t-k}+\sum_{j=1}^{k} \varpi_{j k} \Delta T R_{j t-k}+\sum_{j=1}^{k} \xi_{j k} \Delta P O P G_{j t-k}+v_{j} E C T_{t-1}+\omega_{j t}
\end{aligned}
$$

Where $E C T_{t-1}$ stands for the error margin used to estimate disequilibrium reasons the variables amended to the equilibrium with the intention of keeping the long-run association. While $v_{j}$ refers to the coefficient of adjustment speed and must be negative and significant if a long- run association amongst variables is to happen. 
Bikorimana, G., Rutikanga, C., Butare, G. W., Safari, K. \& Bahizi, M. 2021. Empirical analysis of foreign direct investment on economic growth: evidence from the East African community. International Review of Economics and Management, 9(2), 114-135.

\section{RESULTS AND DISCUSSION}

\section{V.I. Panel Unit Root Test Results}

In making any empirical investigation of macroeconomic time series variables, it is advisable to establish whether the variables under study are stationary or not because, there is a likelihood of producing unreliable results because sing a regression analysis on time series data could produce biased outcomes arising from chance of non-stationary data (Granger \& Newbold, 1974; Perron \& Phillips, 1988). Thus, the unit root test was necessary in finding the order of integration among the study variables. Therefore, the ADF-Fisher chi-square (1999) and PP-Fisher chi-square (2001) panel unit root tests were applied (Levin et al., 2002); Im et al., (2003). The results obtained are reported in Table 2. The calculated p-value for concerned variables was likened to the absolute p-value of $1 \%, 5 \%$, and $10 \%$ respectively.

Table II. Estimation of Panel Data Unit Root Test

\begin{tabular}{|c|c|c|c|c|c|c|c|c|}
\hline & LLC & IPS & ADF -FCS & PP - FCS & LLC & IPS & ADF -FCS & PP - FCS \\
\hline Variables & \multicolumn{4}{|c|}{ Level } & \multicolumn{4}{|c|}{ First Difference } \\
\hline \multirow{2}{*}{ GDP } & -2.713 & -3.853 & 35.511 & 57.592 & $-9.867 * * *$ & $-10.501 * * *$ & $97.014 * * *$ & $128.410 * * *$ \\
\hline & $(0.003)$ & $(0.000)$ & $(0.000)$ & $(0.000)$ & $(0.000)$ & $(0.000)$ & $(0.000)$ & $(0.000)$ \\
\hline \multirow{2}{*}{ LFDI } & -1.409 & -7.409 & 59.328 & 52.739 & $-10.437 * * *$ & $-11.446 * * *$ & $103.440 * * *$ & $119.634 * * *$ \\
\hline & $(0.000)$ & $(0.000)$ & $(0.000)$ & $(0.000)$ & $(0.000)$ & $(0.000)$ & $(0.000)$ & $(0.000)$ \\
\hline \multirow{2}{*}{ LGCF } & 1.152 & 3.176 & 1.253 & 1.167 & $-3.697 * * *$ & $-4.581 * * *$ & $40.972 * * *$ & $71.099 * * *$ \\
\hline & $(0.875)$ & (0.999) & (1.000) & (1.000) & $(0.000)$ & $(0.000)$ & $(0.000)$ & $(0.000)$ \\
\hline \multirow{2}{*}{ LGGFCE } & 0.037 & 2.066 & 2.374 & 3.957 & $-3.585 * * *$ & $-4.979 * * *$ & $44.687 * * *$ & $76.307 * * *$ \\
\hline & $(0.515)$ & $(0.981)$ & (0.993) & (0.949) & $(0.000)$ & $(0.000)$ & $(0.000)$ & $(0.000)$ \\
\hline \multirow{2}{*}{ INF } & -3.412 & -3.499 & 30.652 & 40.645 & $-9.765 * * *$ & $-10.915 * * *$ & $101.347 * * *$ & $134.565^{* * *}$ \\
\hline & $(0.000)$ & $(0.000)$ & $(0.000)$ & $(0.000)$ & $(0.000)$ & $(0.000)$ & $(0.000)$ & $(0.000)$ \\
\hline \multirow{2}{*}{ TR } & -1.603 & -1.638 & 17.301 & 16.428 & $-10.211 * * *$ & $-10.061 * * *$ & $89.741 * * *$ & $81.403 * * *$ \\
\hline & $(0.055)$ & $(0.051)$ & $(0.068)$ & $(0.088)$ & $(0.000)$ & $(0.000)$ & $(0.000)$ & $(0.000)$ \\
\hline \multirow{2}{*}{ POPG } & 0.887 & -3.245 & 33.001 & 14.205 & $-8.215 * * *$ & $-8.552 * * *$ & $75.567 * * *$ & $13.257 * * *$ \\
\hline & $(0.813)$ & $(0.001)$ & $(0.000)$ & $(0.164)$ & $(0.000)$ & $(0.000)$ & $(0.000)$ & $(0.210)$ \\
\hline
\end{tabular}

Notes: LLC; IPS; ADF-FCS and PP-FCS stand for (correspondingly) unit root test in Levin, Lin and Chu (2002); Im, Pesaran and Shin (2003); ADF-Fisher chi-square (1999) and PP-Fisher chi-square (2001). The p-values are indicated in parenthesis. $* * *$ Significance at $1 \%$ level.

Source: Author's computation with data provided

Thereafter, a comparison of calculated and absolute p-value was made, if the calculated p-value is bigger likened to absolute p-value, the null hypothesis of existence of non-stationarity is rejected to support the alternative hypothesis. The findings revealed that, 
Bikorimana, G., Rutikanga, C., Butare, G. W., Safari, K. \& Bahizi, M. 2021. Empirical analysis of foreign direct investment on economic growth: evidence from the East African community. International Review of Economics and Management, 9(2), 114-135.

all variables under study were integrated in order one I (1) which were stationary at a $1 \%$ significant level. Thus, the likelihood of poor regression was ruled out basing on outcomes from panel estimation unit root tests.

\section{V.II. Panel Cointegration Results}

The findings from the unit root test indicated that the variables under study were integrated in order one. In other words, this paper used cointegration techniques to inspect the long-run association between FDI and economic progress. The Pedroni cointegration technique was used and its findings are shown in Table 4. Before doing the test of cointegration, it is required to determine lag order selection criteria. In fact, the results presented in Table 3 show that the three statistical tests used (LR, FPE, and AIC) were subjected to four lags, while the SC and HQ tests were subjected to three lags. Thus, the study selected the use of the optimum lag of 4 as supported by most of the statistical tests.

Table III. Lag Selection Criteria Outcomes

\begin{tabular}{cccccc}
\hline Lag & LR & FPE & AIC & SC & HQ \\
\hline 0 & NA & 1080.137 & 26.850 & 27.0126 & 26.916 \\
1 & 1138.940 & 0.094 & 17.497 & 18.798 & 18.026 \\
2 & 415.294 & 0.0041 & 14.359 & 16.798 & 15.349 \\
3 & 224.671 & 0.001 & 12.883 & $16.4604^{*}$ & $14.336^{*}$ \\
4 & $102.3921^{*}$ & $0.001^{*}$ & $12.574^{*}$ & 17.290 & 14.490 \\
\hline
\end{tabular}

* Shows lag order selected by criteria, LR: sequential modified LR test statistic, FPE: Final prediction error, AIC: Akaike information criterion, SC: Schwarz information criterion, HQ: Hannan-Quinn information criterion Source: Author's computation with data provided

The current study used the Pedroni test of cointegration to test for long-run association between the integrated variables under study. Different tests were used to test for noncointegration in a dynamic panel that permitted heterogeneity between variables (Pedroni, 1999, 2000; Kao, 1999). The outcomes of the Pedroni test of cointegration are presented in table 4. The findings show that the calculated p-value of four from seven Pedroni tests is small at p-value of $5 \%$. This led us to reject the null hypothesis of non-cointegration to support the alternate hypothesis of cointegration. In other words, there cointegration exists amongst the variables under study, justifying the presence of a long-run association amongst the investigated variables. 
Table IV. Pedroni Panel Cointegration Test Results

\begin{tabular}{|c|c|c|c|c|}
\hline \multicolumn{5}{|c|}{ Alternative hypothesis: common AR coefs. (within-dimension) } \\
\hline Panel Group statistics & Statistic & Prob. & $\begin{array}{l}\text { Weighted } \\
\text { Statistic }\end{array}$ & Prob. \\
\hline Panel v-Statistic & 1.681 & 0.046 & -0.494 & 0.689 \\
\hline Panel rho-Statistic & 0.452 & 0.674 & 0.232 & 0.592 \\
\hline Panel PP-Statistic & -6.000 & $0.000 * * *$ & -3.502 & $0.000 * * *$ \\
\hline Panel ADF-Statistic & -5.163 & $0.000 * * *$ & -3.519 & $0.000 * * *$ \\
\hline \multicolumn{5}{|c|}{ Alternative hypothesis: individual AR coefs. (between-dimension) } \\
\hline & Statistic & Prob. & & \\
\hline Group rho-Statistic & 1.024 & 0.847 & & \\
\hline Group PP-Statistic & -4.505 & $0.000 * * *$ & & \\
\hline Group ADF-Statistic & -3.971 & $0.000 * * *$ & & \\
\hline
\end{tabular}

*** Significance at $1 \%$ level.

Source: Author's computation with data provided

\section{V.III. Estimated Vector Error Correction Model of long-run and Granger Causality}

The existence of cointegration amongst variables confirms the existence of a long-run association between FDI and economic progress in EAC member countries. Thus, we applied the VECM method to inspect the long-run and short-run granger causality. VECM offered an approximation of the long-run relationships among the variables under study. Meanwhile, the Pedroni test of cointegration helped to test for the existence of cointegration but did not offer estimates for long-run association. The outcomes of VECM estimation is presented in Tables 5 and 6.

\section{V.III.I. Long-run Equilibrium Association}

Table 5 reports the results of the long-run association among the variables under study. The findings proved that there was a significant and affirmative relationship between FDI and economic growth proxy in terms of GDP per capita. This shows that, an upsurge of $1 \%$ in FDI contributed to the rise of approximately $5.28 \%$ in GDP per capita, which demonstrated economic progress. This outcome was corroborated by Kizilkaya et al., (2016) who investigated on the association between FDI, human capital and economic growth in 39 nations where the pooled OLS and FMOLS methods were used for analysis. Their findings indicated that FDI correlated significantly with economic growth. In addition, this findings of this study are confirmed by Alguacil et al. (2011), Iamsiraroj (2016), Victor \& Christopher (2017) and Mamingi \& Martin (2018).. 
The findings also showed that, the coefficient of gross capital formation is affirmative and statistically significant, implying that the nations with more gross capital formation experienced economic progress. This finding is similar to that of Uneze, (2013) who analyzed the association between capital formation and the economic progress in Sub-Saharan African countries. The results also showed that inflation was negative and statistically significant indicating that a high level of inflation contributed negatively to decreasing the purchasing power of nations, leading to a decline in terms of economic production. In comparison with Peterson's findings (2017) the findings of this study also revealed that population growth rate was negative and statistically significant. This justified the view that the economic situation of EAC member states was not proportional to the population pressure in those countries.

In addition, this study found that the coefficient of trade openness was insignificant and contributed to explaining the variations in terms of economic progress in EAC member states where the influence of government consumption expenditure was negative and statistically insignificant, indicating that excessive government spending discourages economic progress.

Table V. Estimation Result of Long- run

\begin{tabular}{lcccccc}
\hline & $\begin{array}{c}\text { Log } \\
\text { Foreign } \\
\text { Direct } \\
\text { Investmen } \\
\mathrm{t}\end{array}$ & $\begin{array}{c}\text { Log } \\
\text { government } \\
\text { final } \\
\text { consumption } \\
\text { expenditure }\end{array}$ & $\begin{array}{c}\text { Log Gross } \\
\text { capital } \\
\text { formation }\end{array}$ & Inflation & Trade & $\begin{array}{c}\text { Population } \\
\text { growth rate }\end{array}$ \\
\hline Coefficient & 5.288 & -0.105 & 8.611 & -0.224 & 0.046 & -3.776 \\
$\mathrm{t}-$-stat. & {$[7.625]$} & {$[-0.036]$} & {$[3.295]$} & {$[-3.084]$} & {$[0.870]$} & {$[-8.245]$} \\
\hline Explained Variable: GDP per capital & $\begin{array}{c}\mathrm{t} \text {-statistics in [ ] } \\
\text { Source: Author's computation with data provided }\end{array}$
\end{tabular}

\section{V.III.II. Short Run Granger Causality}

Table 6 reported the results from the VECM estimation for the short run granger causality among the variables under study. The findings reported a bi-directional granger causality between GDP per capita growth and population growth rate. This shows that the GDP per capita and population growth complemented each other. This finding is similar to the results obtained by Tsen \& Furuoka, (2005); Jorge Garza et al., (2016); Liu \& Li, (2017) and Gideon et al., (2016). The bi-directional granger causality was also established between foreign direct investment (FDI) and population growth rate, gross capital formation and population growth. This means that changes in FDI and gross capital formation led to changes in corresponding population growth and vice versa. In comparison with other literature 
Bikorimana, G., Rutikanga, C., Butare, G. W., Safari, K. \& Bahizi, M. 2021. Empirical analysis of foreign direct investment on economic growth: evidence from the East African community. International Review of Economics and Management, 9(2), 114-135.

sources, the same results were also obtained by Adel \& Soo, (2015) who noted a bidirectional granger causality between investment and population in Syria.

Table VI. Panel VECM Results

\begin{tabular}{ccccccccc}
\hline $\begin{array}{c}\text { Explained } \\
\text { Variables }\end{array}$ & \multicolumn{7}{c}{ Explanatory Variables (Wald Test: Chi-square value) } \\
\hline & GDP & LFDI & LGGFCE & LGCF & INF & TR & POPG & ECT (-1) \\
\hline \multirow{2}{*}{ GDP } & & 0.839 & $11.187 * * *$ & $5.816^{*}$ & 2.369 & $7.375^{*}$ & $6.466^{*}$ & -0.296 \\
& & $(0.657)$ & $(0.004)$ & $(0.055)$ & $(0.310)$ & $(0.025)$ & $(0.040)$ & {$[-2.050]$} \\
LFDI & 1.296 & & $6.401^{*}$ & $29.478^{* * *}$ & $13.329 * * *$ & $11.511^{* * *}$ & $14.470^{* * *}$ & -0.514 \\
& $(0.523)$ & & $(0.041)$ & $(0.000)$ & $(0.001)$ & $(0.003)$ & $(0.001)$ & {$[-6.378]$} \\
LGGFCE & 3.414 & 1.243 & & 1.809 & 0.537 & 1.672 & 3.635 & -0.0002 \\
& $(0.181)$ & $(0.537)$ & & $(0.405)$ & $(0.765)$ & $(0.433)$ & $(0.162)$ & {$[-1.157]$} \\
LGCF & 2.274 & 1.417 & 0.867 & & 3.717 & 5.865 & $12.094 * * *$ & 0.006 \\
& $(0.301)$ & $(0.492)$ & $(0.648)$ & & $(0.156)$ & $(0.053)$ & $(0.002)$ & {$[0.306]$} \\
INF & 1.830 & 4.367 & 4.168 & 2.919 & & 0.118 & 0.243 & -0.016 \\
& $(0.401)$ & $(0.113)$ & $(0.124)$ & $(0.232)$ & & $(0.943)$ & $(0.886)$ & {$[-0.495]$} \\
TR & 0.586 & 1.389 & 3.881 & $8.253 * *$ & 1.331 & & 2.747 & 0.004 \\
& $(0.746)$ & $(0.499)$ & $(0.144)$ & $(0.016)$ & $(0.514)$ & & $(0.253)$ & {$[0.496]$} \\
POPG & $11.059 * * *$ & $8.684 * *$ & 3.088 & $15.357 * * *$ & 1.659 & 2.590 & -0.058 \\
& $(0.004)$ & $(0.013)$ & $(0.213)$ & $(0.000)$ & $(0.436)$ & $(0.273)$ & {$[-6.623]$} \\
\hline
\end{tabular}

$* * * ; *$ and $*$ stand for Significance level at $1 \%, 5 \%, 10 \%$ respectively,

$\mathrm{P}$-value is indicated in parenthesis, and t-statistics inside is shown in []

Source: Author's computation with data provided

From the above findings, this study found that there is a unidirectional granger causality between government final consumption expenditure and GDP per capita growth. In other words, a change in government final consumption is advantageous in forecasting changes in GDP per capita. The study also found that there is unidirectional causality for GDP per capita and gross capital formation that resulted from gross capital formation. For trade and GDP per capita growth as well as FDI respectively, it was found that a unidirectional granger causality existed between the variables under study cutting across trade and GDP per capita growth as well as trade and FDI.

The results also showed that there was a granger causality between FDI and government consumption expenditure as well as a causality between FDI and gross capital formation; respectively. The type of causality found was unidirectional, running from government consumption expenditure to FDI and from gross capital formation to FDI. This showed that the changes in government consumption expenditure and gross capital formation respectively were advantageous in forecasting the changes in FDI. The findings also established a unidirectional causality among the inflation rates and FDI as well as gross capital formation and trade, respectively. This was crosscutting from inflationary rates to FDI and from gross capital formation to trade. In brief, Table 7 summarizes short-run causality as follows: 


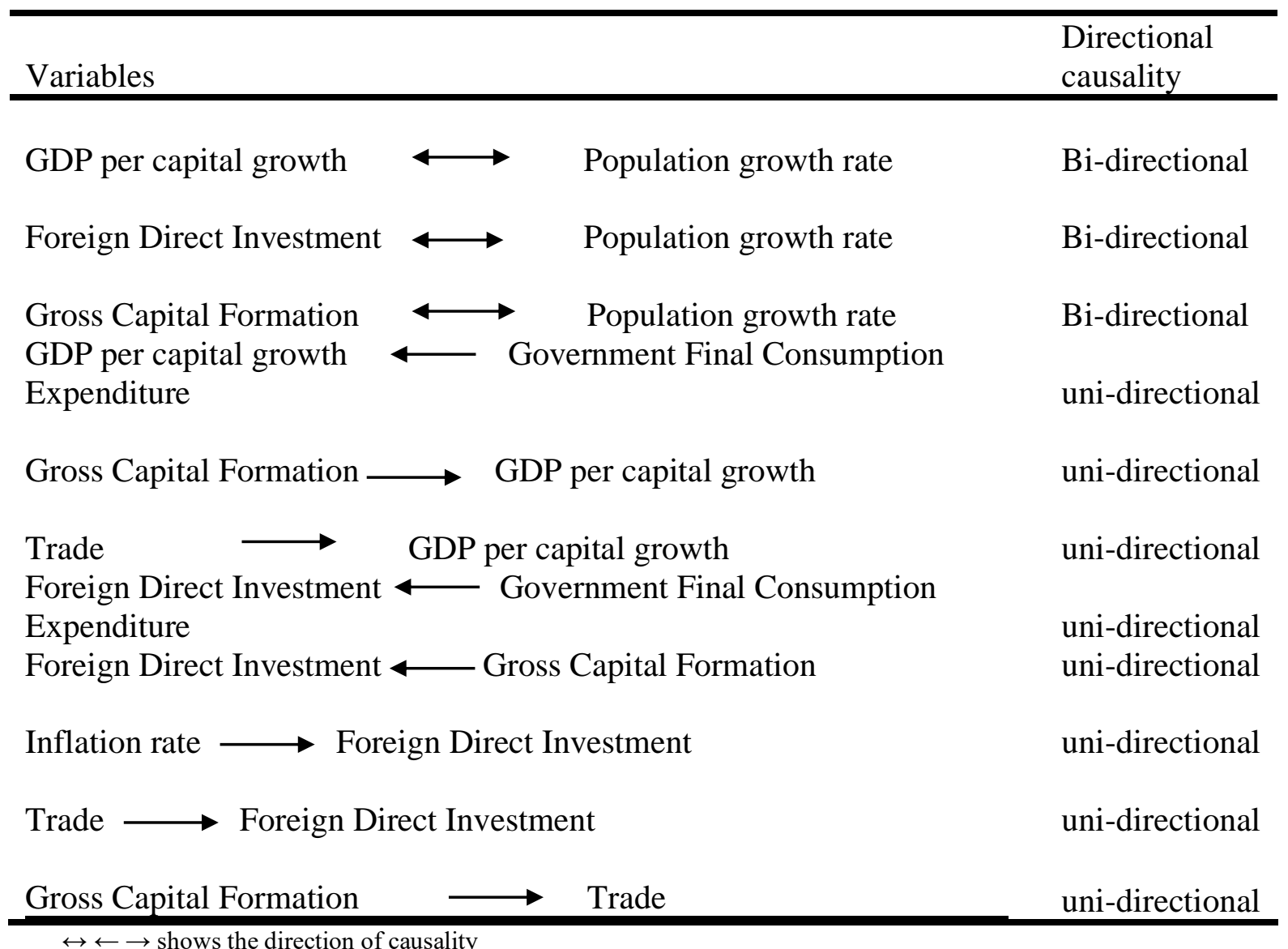

Source: Author's computation with data provided

\section{V.III.III. Long-run Granger causality}

Table 6 presents the outcomes that indicate the results of the ECT coefficient (or speed of adjustment). Enders (2004) indicates the ECT as the level of divergence from long-run equilibrium in the previous period. The ECT coefficient enables to test the speed adjustment factor which indicates the ratio of disequilibrium in subsequent spans. The findings of this study showed that the coefficient results of speed adjustment for GDP per capita growth was 0.296. This was significant at 5\% level indicating that the GDP per capita growth was amended by $29.6 \%$ annually to restore any deviance from its long-run equilibrium.

The findings showed that the coefficient of FDI and population growth rate were both statistically significant and negative ( -0.514 and -0.058 respectively). This implies that the variables of FDI and population growth were smaller than the long-run average and the explanatory variables increased gradually in the long-run to restore any deviance from its long-run equilibrium. This means that the FDI and population growth adjusted by $51.4 \%$ and $5.8 \%$ respectively in one period to restore any deviance from long-run equilibrium. However, other variables were statistically insignificant. 
Bikorimana, G., Rutikanga, C., Butare, G. W., Safari, K. \& Bahizi, M. 2021. Empirical analysis of foreign direct investment on economic growth: evidence from the East African community. International Review of Economics and Management, 9(2), 114-135.

\section{CONCLUSIONS}

The present study empirically analyzed the impact of foreign direct investment on economic growth in the member states of the East Africa Community during the time span of 1990-2017. To achieve its objectives, the study used the Pedroni test of cointegration to test the long-run association of integrated variables used with the study. The VECM tool was also used to inspect the long and short-run granger causality.

The results from unit root test analysis showed that the variables were non-stationary but become stationary after differentiating them at first difference. Thus, the study concluded that the variables were integrated at I (1). The results from the Pedroni cointegration approach and VECM exhibited that FDI is substantially and associated positively with economic progress. This implies that the upsurge of FDI positively impacts economic growth in the member states of the East African Community. Also, the paper found that gross capital formation was affirmative and statistically correlated with economic growth in EAC. The inflation and population growth rate were found to be negative and statistically significantly correlated with economic growth in the EAC member states. Thus, government consumption expenditure and trade, respectively, are negatively and positively statistically insignificant.

The VECM granger causality exploration discovered a bi-directional causality between GDP per capita growth and population growth rate, between FDI and population growth rate, and between gross capital formation and population growth. In addition, a unidirectional granger causality was established among some variables. The study recommended that the East African Community members states should attempt to speed up the process of attracting FDI throughout all the sectors which are preferred by FDI in order to motivate economic progress, gross capital formation, and the labour market. This can be done by strengthening FDI policy in the way that creates a favorable environment to stimulate FDI in the East African Community.

Bu makale araştırma ve yayın etiğine uygun olarak hazırlanmış ve Turnitin kullanılarak intihal taraması yapılmiştır.

(This article was prepared in line with research and publication ethics and scanned for plagiarism by using Turnitin.) 
Bikorimana, G., Rutikanga, C., Butare, G. W., Safari, K. \& Bahizi, M. 2021. Empirical analysis of foreign direct investment on economic growth: evidence from the East African community. International Review of Economics and Management, 9(2), 114-135.

\section{REFERENCES}

Adams, S. (2009). Can foreign direct investment ( FDI ) help to promote growth in Africa ? African Journal of Business Management, 3(5), 178-183. https://doi.org/10.5897/AJBM09.001

Adel Shekeeb Mohsen; Soo Y. Chua. (2015). Effects of Trade Openness, Investment and Population on the Economic Growth: A Case Study of Syria. Hyperion Economic Journal, 3(2), 14-23.

Adeyeye, O. D. A. O. P., \& Olawumi. (2016). “ Impact of foreign direct investment on economic growth in Africa ." Problems and Perspectives in Management, 14(2-2), 289-297. https://doi.org/10.21511/ppm.14(2-2).2016.04

Alfaro, L., Chanda, A., Kalemli-Ozcan, S., \& Sayek, S. (2004). FDI and economic growth: The role of local financial markets. Journal of International Economics, 64(1), 89-112. https://doi.org/10.1016/S00221996(03)00081-3

Alguacil, M., Cuadros, A., \& Orts, V. (2011). Inward FDI and growth: The role of macroeconomic and institutional environment. Journal of Policy Modeling, 33(3), 481-496. https://doi.org/10.1016/j.jpolmod.2010.12.004

Ang, J. B. (2009). Foreign direct investment and its impact on the Thai economy: the role of financial development. Journal of Economics and Finance, 33, 316-323. https://doi.org/10.1007/s12197-008-90426

Balasubramanyam, V. N., Salisu, M., \& Sapsford, D. (1996). Foreign Direct Investment and Growth in EP and is Countries. The Economic Journal, 106(434), 92-105. https://doi.org/10.2307/2234933

Barro, R. J. (1991). Economic Growth in a Cross Section of Countries. The Quarterly Journal OfEconomics, 106(2), 407-443.

Bellak, C., \& Leibrecht, M. (2016). The Use of Investment Incentives: The Cases of R\&D-Related Incentives and International Investment Agreements. In: Tavares-Lehmann, A., Toledano, P., Johnson, L. and Sachs, L. (Eds.) Rethinking Investment Incentives: Trends and Policy Options. Columbia University Press, New York, Pp. 63-93. ISBN 9780231172981. https://doi.org/10.7312/tava17298-005

Belloumi, M. (2014). The relationship between trade, FDI and economic growth in Tunisia: An application of the autoregressive distributed lag model. Economic Systems, 38(2), $269-287$. https://doi.org/10.1016/j.ecosys.2013.09.002

Carkovic, M., \& Levine, R. E. (2002). Does Foreign Direct Investment Accelerate Economic Growth? SSRN Electronic Journal, 195-220. https://doi.org/10.2139/ssrn.314924

Dickey, D. A. (1979). Distribution of the Estimators for Autoregressive Time Series with a Unit Root. Journal of the American Statistical Association, 74(366a), 427-431.

E. Borensztein , J. De Gregorio, J.-W. L. (1998). How does foreign direct investment affect economic growth? Journal of International Economics, 45, 115-135. https://doi.org/10.1080/10978526.2010.486715

EAC[EAST AFRICAN COMMUNITY]. (2011). EAC Development Strategy ( 2011 / 12 - 2015 / 16 ) Deepening And Accelerating Integration One People, One Destiny.

Enders, W. (2004). Applied Econometric Time Series, 2nd edition. Wiley \& Son Inc: Hoboken, New Jersey, USA.

Gideon Kiguru Thuku, Gachanja Paul, O. A. (2016). The Impact of Population Change on Economic Growth in Kenya. International Journal of Economics and Management Sciences, 2(6), 43-60. https://doi.org/http://dx.doi.org/10.1108/09564230910978511

GRANGER, C. W. J., \& NEWBOLD, P. (1974). Spurious Regressions in Econometrics. Journal of Econometrics, 2, 111-120. https://doi.org/10.1002/9780470996249.ch27

Gunby, P., Jin, Y., \& Robert Reed, W. (2017). Did FDI Really Cause Chinese Economic Growth? A MetaAnalysis. World Development, 90, 242-255. https://doi.org/10.1016/j.worlddev.2016.10.001

Herzer, D., Nowak-Lehmann, F. D., \& Siliverstovs, B. (2006). Export-led growth in Chile: Assessing the role of export composition in productivity growth. The Developing Economies, 44(3), 306-328. https://doi.org/10.1111/j.1746-1049.2006.00019.x

Iamsiraroj, S. (2016). The foreign direct investment-economic growth nexus. International Review of Economics and Finance, 42, 116-133. https://doi.org/10.1016/j.iref.2015.10.044 
Bikorimana, G., Rutikanga, C., Butare, G. W., Safari, K. \& Bahizi, M. 2021. Empirical analysis of foreign direct investment on economic growth: evidence from the East African community. International Review of Economics and Management, 9(2), 114-135.

Im, K. S., Pesaran, M. H., \& Shin, Y. (2003). Testing for unit roots in heterogeneous panels. Journal of Econometrics, 115(1), 53-74. https://doi.org/10.1016/S0304-4076(03)00092-7

IMF [International Monetary Fund]. (2016). World Economic Outlook: Subdued Demand: Symptoms and Remedies. Washington, D.C.

Jorge Garza-Rodriguez, Cecilia I. Andrade-Velasco, Francisco D. Renteria-Rodriguez, Karen D. Martinez-Silva, P. A. V.-C. (2016). The relationship between population growth and economic growth in Mexico. Economics Bulletin, 36(1), 1-13.

Kao, C. (1999). Spurious regression and residual-based tests for cointegration in panel data. Journal of Econometrics, 90, 1-44.

Kevin Honglin Zhang. (2001). Does Foreign Direct Investment Promote Economic Growth? Evidence from East Asia and Latin America. Contemporary Economic Policy, 19(2), 175-185. https://doi.org/10.1111/j.14657287.2001.tb00059.x

Kizilkaya, O., Ay, A., \& Akar, G. (2016). Dynamic relationship among foreign direct investments, human capital, economic freedom and economic growth: Evidence from panel cointegration and panel causality analysis. Theoretical and Applied Economics, XXIII(3608), 127-140.

Laura Alfaro, Areendam Chanda, Sebnem Kalemli-Ozcan, S. S. (2003). FDI and Economic Growth: The Role of Local Financial Markets. Journal of International Economics, 713-743.

Levin Andrew, Chien-Fu Lin, C.-S. J. C. (2002). Unit root tests in panel data:asymptotic and "nite-sample properties. Journal of Econometrics, 108, 1-24. https://doi.org/10.1097/00000441-191105000-00057

Liu, L., \& Li, W. (2017). The relation between population and economic development based on empirical research on dynamic VEC model in Xinjiang, 32(14), 206-215.

Liu, X., Burridge, P., \& Sinclair, P. J. N. (2002). Relationships between economic growth, foreign direct investment and trade: Evidence from China. Applied Economics, 34(11), 1433-1440. https://doi.org/10.1080/00036840110100835

Magnus Blomstrom, Robert E. Lipsey, M. Z. (1992). What Explains Developing Country Growth (No. Working Paper No.4132). National Bureau of Economic Research, Cambridge, MA 02138.

Mah, J. S. (2010). Foreign direct investment inflows and economic growth of China. Journal of Policy Modeling, 32, 155-158. https://doi.org/10.1016/j.jpolmod.2009.09.001

Mamingi, N., \& Martin, K. (2018). Foreign direct investment and growth in developing countries: Evidence from the countries of the Organisation of Eastern Caribbean States. CEPAL Review, (124), 79-98. https://doi.org/10.18356/e270b670-en

Masipa, T. S. (2018). The relationship between foreign direct investment and economic growth in South Africa : Vector error correction analysis. Acta Commercii, 18(1), 1-8. https://doi.org/doi.org/10.4102/ ac.v18i1.466

Mehic, E., Silajdzic, S., \& Babic-Hodovic, V. (2013). The Impact of FDI on Economic Growth: Some Evidence from Southeast Europe. Emerging Markets Finance and Trade, 49(sup1), 5-20. https://doi.org/10.2753/ree1540-496x4901s101

Mounir Belloumi, Atef, A. (2018). The Impacts of Domestic and Foreign Direct Investments on Economic Growth in Saudi Arabia. Economies, 1-17. https://doi.org/10.3390/economies6010018

Naguib, R. I. (2012). The effects of privatisation and Foreign Direct Investment on economic growth in Argentina. The Journal of International Trade \& Economic Development: An International and Comparative Review, 21(1), 51-82. https://doi.org/10.1080/09638199.2012.643014

Nicet-Chenaf, D., \& Rougier, E. (2009). FDI and growth: A new look at a still puzzling issue.

Olawumi D. Awolusi, Olufemi P. Adeyeye, T. G. P. (2017). Foreign direct investment and economic growth in Africa: A comparative analysis. Int. J. Sustainable Economy, 9(3), 183-198. https://doi.org/10.1504/IJSE.2017.085062

Onyebuchi Asogwa and Manasseh Charles Osondu. (2014). The impact of Foreign Direct Investment on Economic Growth in Niger. IOSR Journal of Economics and Finance, 3(5), 37-45. https://doi.org/10.9790/5933-0802032833

Ozturk, I. (2007). Foreign Direct Investment - Growht Nexus: A Review of The Recent Literature. International Journal of Applied Econometrics and Quantitative Studies, 4(2), 79-98.

Pedroni, P. (1999). Critical Values for Cointegration Tests in Heterogeneous Panels with Multiple Regressors. 
Bikorimana, G., Rutikanga, C., Butare, G. W., Safari, K. \& Bahizi, M. 2021. Empirical analysis of foreign direct investment on economic growth: evidence from the East African community. International Review of Economics and Management, 9(2), 114-135.

Oxford Bulletin of Economics and Statistics, 61, 653-670.

Pedroni, P. (2000). Fully Modified OLS for Heterogeneous Cointegrated Panels. Advances in Econometrics, 15, 93-130.

Pedroni, P. (2004). Panel cointegration: Asymptotic and finite sample properties of pooled time series tests with an application to the PPP hypothesis. Econometric Theory, 20(3), 597-625. https://doi.org/10.1017/S0266466604203073

Pegkas, P. (2015). The impact of FDI on economic growth in Eurozone countries. The Journal of Economic Asymmetries, 12(2), 124-132. https://doi.org/10.1016/j.jeca.2015.05.001

Penev, S., \& Marusic, A. (2014). Attractiveness of East African Community (EAC) for Foreign Direct Investment. Economic Analysis, 47, 35-49.

Perron, P., \& Phillips, P. C. B. (1988). Testing for a Unit Root in a Time Series Regression. Biometrika, 75(2), 335-346. https://doi.org/10.1080/07350015.1992.10509923

Peterson, E. W. F. (2017). The role of population in economic growth. SAGE Open, 1-15. https://doi.org/10.1177/2158244017736094

Philip Alege and Adeyemi Ogundipe. (2013). Sustaining Economic Development of West African Countries: A System GMM Panel Approach. MPRA Paper No. 51702. Covenant University, Ota, Ogun State. Nigeria.

Sakyi, D., \& Egyir, J. (2017). Effects of trade and FDI on economic growth in Africa: an empirical investigation. Transnational Corporations Review. https://doi.org/10.1080/19186444.2017.1326717

Solow, R. M. (1956). A Contribution to the Theory of Economic Growth. The Quarterly Journal of Economics, 70(1), 65-94.

Soltani, H., \& Ochi, A. (2012). Foreign Direct Investment (FDI) and Economic Growth: an approach in terms of cointegration for the case of Tunisia. Journal of Applied Finance \& Banking, 2(4), 193-207.

Stmatiou \& Dritsakis. (2013). A Causal Relationship between Exports , Foreign Direct Investment and Economic Growth for five European countries. A panel data. Presented at the 12th annual EEFS conference, Berlin, Germany, 20-23 June. https://doi.org/10.13140/2.1.5080.0329

Syed Zia Abbas Rizvi \& Muhammad N. (2009). The Impact of Foreign Direct Investment on Employment Opportunities: Panel Data Analysis : Empirical Evidence from Pakistan, India and China. The Pakistan Development Review, 48, 841-851. https://doi.org/10.30541/v48i4IIpp.841-851

Tsaurai, K., Odhiambo, M. N. (2012). Foreign direct investment and economic growth in Zimbabwe : a dynamic causality test. Int. J. Economic Policy in Emerging Economies, 5(2).

Tsen, W. H., \& Furuoka, F. (2005). The Relationship between Population and Economic Growth in Asian Economies. Asean Economic Bulletin, 22(3), 314-330. https://doi.org/10.1355/ae22-3e

UNCTAD. (2015). World Investement Report 2015: Reforming International Investment Governance. New York and Geneva. United Nations, Geneva.

UNCTAD. (2018). World Investment Report 2018. Investment and new industrial policies. United Nations Publications, Geneva. https://doi.org/10.18356/a1e0466b-en

Uneze, E. (2013). The relation between capital formation and economic growth: Evidence from sub-Saharan African countries. Journal of Economic Policy Reform, 16(3), 272-286. https://doi.org/10.1080/17487870.2013.799916

Victor Owusu-Nantwi; Christopher Erickson. (2017). Foreign Direct Investment and Economic Growth in South America. Journal of Social Economics. https://doi.org/10.1108/ijse.2006.00633baa.001

Xinfeng Yan, Majagaiya, K. P. (2011). Relationship between Foreign Direct Investment and Economic Growth Case Study of Nepal. International Journal of Business and Management, 6(6), 242-246. https://doi.org/10.5539/ijbm.v6n6p242

Xinshen Diao, Margaret McMillan, D. R. (2017). The Recent Growth Boom in Developing Economies: A Structural-Change Perspective. Working Paper. Cambridge, MA: National Bureau of Economic Research; World Bank Economic Review.

Zekarias, S. M. (2016). The Impact of Foreign Direct Investment ( FDI ) on Economic Growth in Eastern Africa: Evidence from Panel Data Analysis. Applied Economics and Finance, 3(1), 145-160. https://doi.org/10.11114/aef.v3i1.1317 